\section{AMMONITES AND CHRONOLOGY OF THE JURASSIC}

Jurassic Geology of the World

By Dr. W. J. Arkell. Pp. xiv $+806+46$ plates. (Edinburgh and London: Oliver and Boyd, Ltd., 1956.) 105s. net.

THE author of "The Jurassic System in Great Britain" (1933) has capped that notable work with this equally substantial volume. Starting with Great Britain, where the succession of Jurassic formations was first determined, Dr. W. J. Arkell conducts his reader on a world tour, continent by continent, giving for each region a concise account of the rocks of this system and a critical review of the evidence as to the exact stages which they represent. Ammonite assemblages are the dominant theme throughout the work, the object of which, Dr. Arkell states, is in "no small part . . . to test the principles and performance of palæontological correlation on a world scale, to establish its capabilities and limitations". Bibliographies are given for each region, and Jurassio outcrops are indicated in numerous sketch maps. Some previously unpublished matter has been incorporated. The work is a mine of information and will be indispensable for reference.

Many will remember the controversies which, thirty years or more ago, centred around S. S. Buckman, who taught that ever-increasing precision was possible in the correlation of Jurassic rocks throughout the world on the basis of the distribution of ammonites, if only specimens were accurately collected and very critically examined. His culminating effort was to produce a scheme of about 370 'hemerae' into which, he alleged, it was practicable to divide Jurassic time. Ammonite evolution and the universal dispersal of new forms were, he maintained, so rapid that, if marine rocks deposited during any one of these hemerae were present in any region, the ammonite assemblage which then flourished everywhere would be found in them ; and the absence of any such assemblage would indicate a local gap in the rock succession. A few thought that Buckman's scheme was entirely based on careful field-work (he certainly knew the Middle Jurassics of the Cotswolds thoroughly), others regarded him as a prophet who had divined the truth; but there were unbelievers who pointed out that his ideas were contrary to present-day experience of faunal provinces and the dependence of distribution on ecological factors. His doctrines were, at least, a stimulus to accurate collecting. Time has now put them to the test, and we turn with interest to Dr. Arkell's pronouncements on the subject.

That the rapidly evolving, prolific and (apparently) mostly very mobile ammonites afford the most reliable basis at present known to us for the correlation of marine Mesozoic rocks is a universally accepted fact. In the Lias, moreover, there is very little evidence of the existence of faunal provinces, the distribution of many genera being world-wide. As we ascend in the Jurassic succession, however, three faunal provinces (Tethyan, Pacific and Boreal) become distinguishable, contesting for certain regions. In the most favourable circumstances, where rocks of suitable lithology occur, a considerable degree of precision in correlation within a restricted area is possible with the aid of ammonites. Over any wide area, however, zonal schemes, much less detailed than those of Buckman, break down, and the original series of zones promulgated by Oppel in 1856-58 (amounting to about one-tenth the number of Buckman's hemerae) lies at about the limit of practical utility. Further, Dr. Arkell's considered view is that the original eleven stages into which d'Orbigny divided the Jurassic system in 1850 form "by far the best scheme yet devised for classification on a world scale". Even these are not applicable universally for the uppermost Jurassic ; here we still have no means of exact correlation between d'Orbigny's Portlandian and Purbeckian in north-west Europe, the Volgian of Russia, and the Tithonian of the rest of the world. These conclusions are both a testimony to the acumen of the pioneers and a reminder that applied palæontology cannot be expected to progress on the same lines as a mathematical science. An interesting episode in the history of palæontological theory must be considered finally closed.

The concluding chapters of the work deal with other matters of general interest. Dr. Arkell is on the side of those who advocate the permanence of the main ocean basins. He bas no use for palæogeographical maps, especially those showing continental masses occupying the present North Atlantic and Pacific basins in Jurassic times. Of continental drift since the Jurassic, he finds no evidence.

L. R. Cox

\section{PROGRESS IN NUCLEAR SCIENCE}

\section{Annual Review of Nuclear Science}

Vol. 5, 1955. Edited by James G. Beckerley, in association with Martin D. Kamen and Leonard I. Schiff. Pp. $\mathrm{x}+448$. (Stanford, Calif. : Annual Reviews, Inc., in co-operation with the National Research Council of the National Academy of Sciences, 1955.) 7 dollars.

CHIS is the fifth volume to appear in this series. The individual articles range widely from theoretical nuclear physics through nuclear engineer. ing and radiation chemistry to radiobiology. Such publications must eschew the ephemeral progress report, the too-specialized description of experimental work or the very general treatment which properly belongs in a text-book. This volume generally avoids these hazards. The literature surveys are up to date to within about a year ago.

In a review of present knowledge of electromagnetic transitions in nuclei, Goldhaber and Weneser discuss the relative success of various nuclear models in explaining the regularities observed experimentally. Ford and Hill discuss the recent experimental information that has led to a detailed and consistent picture of the charge distribution in the nucleus. Theoretical explanations of this distribution, however, still seem inadequate. Peaslee contributes a survey of a field which has been receiving much attention recently--that of nuclear reactions in the intermediate energy-range up to $20 \mathrm{MeV}$. Here the compound nucleus model is ceasing to be applicable, and the more direct knockon processes familiar at high energy have not yet become predominant. Two extreme models, the optical model and the statistical model, have each had some success. However, the experimental information available so far is rather incomplete.

Fretter supplies a useful article of the handbook type on the cloud chambers and bubble chambers being exploited in high-energy physics. Blizard dis- 